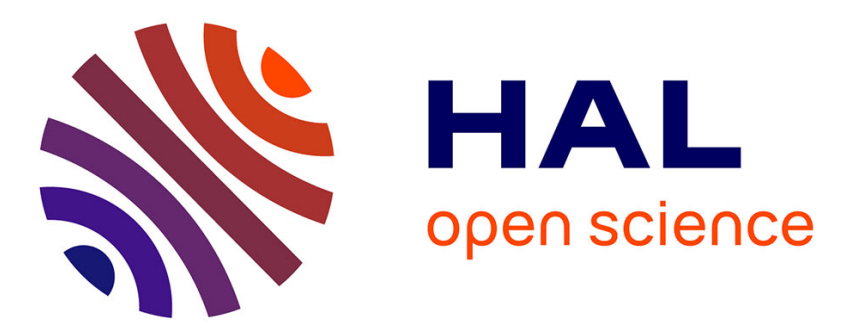

\title{
Land use and climate change effects on soil erosion in a semi-arid mountainous watershed (High Atlas, Morocco)
}

Vincent Simonneaux, Aouatif Cheggour, Charles Deschamps, Florent

Mouillot, Olivier Cerdan, Yves Le Bissonnais

\section{- To cite this version:}

Vincent Simonneaux, Aouatif Cheggour, Charles Deschamps, Florent Mouillot, Olivier Cerdan, et al.. Land use and climate change effects on soil erosion in a semi-arid mountainous watershed (High Atlas, Morocco). Journal of Arid Environments, 2015, 122, pp.64-75. 10.1016/j.jaridenv.2015.06.002 . ird-01199053

\section{HAL Id: ird-01199053 \\ https://hal.ird.fr/ird-01199053}

Submitted on 14 Sep 2015

HAL is a multi-disciplinary open access archive for the deposit and dissemination of scientific research documents, whether they are published or not. The documents may come from teaching and research institutions in France or abroad, or from public or private research centers.
L'archive ouverte pluridisciplinaire HAL, est destinée au dépôt et à la diffusion de documents scientifiques de niveau recherche, publiés ou non, émanant des établissements d'enseignement et de recherche français ou étrangers, des laboratoires publics ou privés. 


\title{
Land use and climate change effects on soil erosion in a semi-arid mountainous watershed (High Atlas, Morocco).
}

\author{
Simonneaux Vincent ${ }^{a}$, Cheggour Aouatif ${ }^{b}$, Deschamps Charles $^{a}$, Mouillot Florent ${ }^{c}$, Cerdan \\ Olivier $^{d}$, Le Bissonnais Yves ${ }^{e}$
}

(a) Corresponding author

CESBIO (Centre d'Etudes Spatiales de la Biosphère, UMR CNES-CNRS-IRD-UPS), 18 Av. Edouard Belin, 31401 Toulouse cedex 9, France.

Tel. +33 (0) 5615585 42, Fax +33 (0)561558500

vincent.simonneaux@ird.fr

(b) Université Cadi Ayyad. Département de Géologie, 40000 Marrakech, Maroc. geol ch@yahoo.fr

(c) CEFE/CNRS, Campus du CNRS, 1919, route de Mende, 34293 Montpellier 5 florent.mouillot@cefe.cnrs.fr

(d) BRGM, RNSC / RMT, B.P. 6009, 3 Av. Claude Guillemin, 45060 Orléans, France o.cerdan@brgm.fr

(e) INRA, UMR LISAH (INRA-IRD-SupAgro), Campus AGRO, place Viala, 34060 Montpellier, France.

yves.le-bissonnais@supagro.inra.fr

\begin{abstract}
The objective of this study was to simulate the evolution of soil erosion in a semi-arid mountainous watershed $\left(225 \mathrm{~km}^{2}\right.$, High Atlas Mountains, Morocco) under different scenarios of climate and land use change to the end of 21 st century. Erosion plots monitored over four years showed spatially contrasted results. Most of the soils produced from 0.015 to $2.5 \mathrm{t} \mathrm{ha}^{-1}$ $\mathrm{y}^{-1}$, whereas badlands produced $350 \mathrm{tha}^{-1} \mathrm{y}^{-1}$. The average sediment yield measured at the outlet during the same period was approximately $4 \mathrm{t} \mathrm{ha}^{-1} \mathrm{y}^{-1}$.

The STREAM distributed erosion model was parameterized using these field measurements (infiltration rates and runoff sediment concentrations). The results showed an overall agreement between the modeled and measured annual cumulative sediment yields.

Simulations of the ARPEGE meteorological model were used for the 1960-1990 and 20702100 periods. The changes between these two periods were downscaled using three different methods, decreasing annual precipitations by 10 to $14 \%$, although with more rainfall in summer and fall. Climate change alone increased sediment yield by 4.7 to $10.1 \%$. However, simulations showed that land use changes might potentially induce much larger changes in erosion (up to $250 \%$ ), approximately proportional to the evolution of the extension of badlands.
\end{abstract}

Keywords: Erosion plots; Erosion Modeling; Runoff; Sediment Yield; Badlands; Climate Downscaling; Land Use Change 


\section{Introduction}

The consensus of climate scientists is that the Earth is warming, and as global temperatures increase, the hydrologic cycle is becoming more vigorous. Climate models are predicting a continued increase in intense precipitation events during the 21 st century (IPCC, 2013). Both soil erosion and its consequences will be influenced by these climate and land use changes. Because of their interactions, the effects of future climate and land use changes must be considered together. In fact, climate change has both direct and indirect effects upon soil erosion.

Direct effects are due to changes in the amount, erosive power and temporal pattern of rainfall. The soil system tends to react nonlinearly to such changes, so even small increases in rainfall amount or intensity can result in dramatically increased rates of soil loss, especially if rainfall occurs on unprotected soil surfaces resulting from land use change or fire (Nearing et al., 2005). Climate change could lead to a temporal shift in both the vegetation cover and the rainfall pattern. If this leads to heavier rainfall on less-protected soils (bare soils due to human activity, such as tillage, or due to a shift in the vegetation cycle), large increases in erosion rates are to be expected. Conversely, if rainfall tends to occur during periods of greater soil protection due to vegetation, lower soil erosion will happen. Indirect effects result from the effects of increased atmospheric $\mathrm{CO}_{2}$ concentrations on crop growth and - more dramatically - from climate-driven changes in land use. Increased carbon dioxide has a fertilizing effect on many crops. However, increases in rainfall during the vulnerable period of early growth will readily overcome this ameliorating effect. The most dramatic increases in erosion are likely to result from a change in land use to more erosion-prone crops and less protective vegetation.

The Mediterranean climate is characterized by seasonal contrast, where the dry and warm summer climate can affect the soil erodibility, e.g., through lower vegetation cover and lower aggregate stability (Le Bissonnais et al., 2007), and where the concentration of precipitation events, particularly in the fall, affects the soil erosion (Ramos and Martínez-Casasnovas, 2009). In addition, the Mediterranean region lies in a transition zone between the arid climate of North Africa and the rainy climate of central Europe, and is thus potentially more vulnerable to climatic changes including a possible temperature increase and a general reduction in the estimated precipitation (Giorgi and Lionello, 2008). This climate change is expected to induce the evolution of land use (Olesen and Bindi, 2002). Land use is a key parameter of soil erosion in a landscape, controlling the soil characteristics (cover vegetation, roughness, infiltration capacity, etc.) and the distribution of the overland flow by land management (e.g., drainage and ditch). The estimated soil loss rates are often superior to the soil production rates (Kosmas et al., 1997), a result of land use that encourages erosion such as vineyards (Casalí et al., 2009), olive groves (Fleskens and Stroosnijder, 2007) and extensive overgrazing in mountain areas (Cerdan et al., 2010). Land abandonment, which occurs frequently in the Mediterranean and might increase with climate change, is playing a key role, potentially increasing erosion in young fallows (Cerda, 1997).

Global change will thus amplify many current problems of soil erosion. The climatic changes and increasing anthropic pressure, both of which threaten the sustainability of the soils, may lead to desertification, especially in the southern Mediterranean region and in mountainous areas. However, because of the complexity of the processes and interactions between parameters and the lack of validation data, a wide range of uncertainty in the direction and magnitude of the impacts of global change on soils and vegetation is to be expected. 
Risk assessment of future soil erosion is therefore of primary importance, both for land managers and for water and dam managers to estimate sediment exportations from watersheds and siltation of dams $(0.5 \%$ of the total water storage capacity of Moroccan dams is lost each year) (Ghanam, 2003). As many watersheds are ungauged, robust models are needed for sediment exportation estimates. Different types of erosion models have been developed for small watersheds on an event to annual time scale (Jetten and Favis-Mortlock, 2006). On the one hand, the ability of simple empirical models such as USLE to integrate the dominant processes at the watershed scale is debatable (Imeson and Kirkby, 1996, Wainwright et al., 2008, Smith et al., 2010). On the other hand, complex process-based models require numerous input data that are generally not available and difficult to measure (Takken et al., 1999). In such a context, it has been shown that simple process-based models such as STREAM (Cerdan et al, 2002) offer a reliable alternative option for regions where limited data are available (Evrard et al., 2009) or for larger watersheds where precise input data are lacking (King et al., 2005). Whichever model is used, a minimum set of field experimental records is necessary in order to calibrate and validate the model. Field measurements of erosion are rarely available at the watershed scale over long periods. Another difficulty for modeling erosion within large watersheds comes from the scale effect. Runoff and erosion responses can vary greatly at different scales. This variability may be due to the spatial variability of erosion parameters within the watershed and/or to the emergence of new water and sediment production and transfer processes, which occur when moving from a homogeneous hydrological unit to a heterogeneous watershed (Imeson and Lavee, 1998, Parsons et al., 2006, Canton et al., 2011).

In this context, the objectives of this paper are as follows: (1) to assess the current erosion rates and processes in a semi-arid mountainous watershed of $225 \mathrm{~km}^{2}$, using four years of runoff and erosion monitoring at the plot and outlet scale; (2) to test the ability of the distributed STREAM model to correctly predict sediment yield variability; and (3) to simulate the soil erosion risk in this watershed under different scenarios of climate and land use change to the end of 21 st century.

\section{Study area}

The study area is the Rheraya catchment $\left(225 \mathrm{~km}^{2}\right)$, which is one of the main mountainous sub-watersheds of the Tensift watershed in the High Atlas range of Morocco, with altitudes ranging from 1084 to $4167 \mathrm{~m}$ a.s.l. (Fig. 1). The geology of the area includes sedimentary formations in the foothills located in the northern third of the area, with limestone, marl and very erodible red clay loam (permotrias) formations producing local, highly eroded badlands. Magmatic rocks (andesite, granite) are encountered in the high mountains located in the twothirds south of the watershed. The land use mainly includes degraded rangelands on the mountainsides, with chamaephyte coverage that is usually very scarce due to overgrazing. Some thuya woodlands are present on the northern foothills, which receive higher precipitation. Irrigated crops are encountered around the main hydrological network, covering about five percent of the total area. Finally, some dry farming occurs on some gentle limestone slopes north of the watershed.

The watershed is monitored for hydrologic characteristics since 1989. Precipitations are very variable in space, with an average annual rainfall ranging between 300 and $700 \mathrm{~mm}$ depending on the site location. The average value for the watershed is estimated around 490 $\mathrm{mm}$, approximately one third of it falling as snow (Cheggour, 2008a). Annual rainfall depths 
are also variable in time, ranging from 200 to $600 \mathrm{~mm}$ during the monitoring period at the outlet. Rainfall is distributed throughout the year with a typical minimum value between June and September (Fig. 2). Precipitation occurs mostly as long, low intensity events in winter and localized thunderstorms during spring and summer. The evapotranspiration in this area is poorly known; however, a weather station installed by the SudMed project at Aremd (1900 $m$ a.s.l.) inside the catchment gave an average Penman-Monteith reference evapotranspiration value of $1073 \mathrm{~mm}$ from 2003 to 2006. The average runoff at the outlet at Tahanaout over the period 1989-2006 was $1.44 \mathrm{~m}^{3} \mathrm{~s}^{-1}\left(202 \mathrm{~mm} \mathrm{y}^{-1}\right)$, with the average monthly distribution presented in figure 2 .


Fig. 1. Location of the Rheraya watershed, included in the Tensift watershed.



Fig. 2. Monthly distribution of runoff and rainfall depths at Tahanaout over 19702002. The error bars show the standard deviation of monthly observations over the period. (from Chaponnière, 2008). 


\section{Material and methods}

\subsection{Field measurements}

The watershed was equipped with two automatic rain gauges located north and south of the basin and nine manual rain gauges providing cumulative rainfall event depths, which were added to capture the spatial variability of the precipitation field. The rainfall data collected between 2004 and 2008 were used both for calculating current erosion trends and for elaborating future climatic scenarios.

Six erosion plots of approximately $150 \mathrm{~m}^{2}$ were monitored between 2004 and 2008 (Cheggour, 2008a). Three sites were located on magmatic substratum, the dominant soil type in the watershed, while three others were located on red clay loam, which has the highest contribution to erosion. The plots were located on rangelands, covering more than $90 \%$ of the area. However, two plots, one for each substratum, were located on pine plantations on embankments, a widespread conservation practice in the area.

Twenty-two infiltration-runoff tests were also performed for various sites inside the watershed. These tests were carried out on $1 \mathrm{~m}^{2}$ micro-plots located a few meters from the erosion plots and simulating 30 min rains with an intensity of $80 \mathrm{~mm} \mathrm{~h}^{-1}$ (Cheggour et al., $2008 \mathrm{~b})$. These tests provided indicators of infiltration capacity and estimates of runoff sediment concentration.

Sediment yield measurements at the outlet were recorded during the same period used for the plots (Cheggour, 2008a). The outlet of the watershed was equipped by the watershed agency (ABHT), who measured flow depth three times a day through visual observations on a gauge. Streamflow gauging was performed either every month or after each strong event to reassess and adjust the calibration curves of the flow depth-flow rate relationship. During flood events, the frequency of measurements was increased in order to integrate the significant variations in flow depth. During these events, $500 \mathrm{ml}$ samples of water were also taken periodically to estimate the sediment concentration (i.e., approximately 5 to 20 samples for each event). Moreover, samples of water were also taken every week to estimate the concentration of base flow sediment concentration. All samples were collected from the river by hand and were analyzed using filtration, drying and weighting of the dry matter. Samples of low sediment concentration were analyzed using vacuum filtration. These measurements were processed using the Hydraccess software (Vauchel, 2005) to integrate the streamflow at hourly time steps and calculate the water and sediment yield of each event. The water and sediment yield of each flood event were calculated as the extra water and sediment above the base flow values observed just before the event. When rainfall events occurred so closely that it was not possible to distinguish between their individual contributions, they were aggregated into a single long flood event.

\subsection{The modeling approach}

We used the STREAM model (Cerdan et al., 2002), a simple process-based distributed erosion model initially designed for agricultural landscapes. The model works for single rain events, which are characterized by rainfall depth, duration, maximum intensity in five minutes and antecedent rainfall. Three drivers of erosion, namely, the vegetation cover, the soil surface characteristics and the soil roughness, are entered by the user into a map of homogeneous land units (either agricultural fields or natural vegetation units). A set of rules 
is built by the user to associate each combination of the three parameters with an infiltration capacity and runoff sediment concentration. STREAM uses a hortonian hypothesis for each pixel's runoff generation (overland flow is generated when water input exceeds infiltration rate), which is subsequently routed down slope using a DEM and specified preferential flow paths. Neither saturation excess overland flow nor subsurface runoff and subsequent exfiltration are represented. Although the STREAM model has already been applied to different environments including Mediterranean settings (Evrard et al., 2009; Frot and Van Wesemael, 2009), it has not yet been implemented in semi-arid mountainous areas.

\subsection{Model parameterization and calibration from field data}

\subsubsection{Mapping STREAM input parameters}

The adaptation of this model to the context of the Rheraya watershed, which has mostly rangelands instead of crops, led us to identify the three main parameters driving soil infiltration and erodibility. Based on the results of various measurements (Cheggour, 2008a, $2008 \mathrm{~b})$ and a field survey, the following parameters were identified:

(1) the soil type, which is strongly linked to parent material;

(2) the soil protection by vegetation or stones;

(3) the soil conservation practices, namely terraces (irrigation) of embankments associated with trees plantations.

The soil type and conservation practices were mapped based on the 1:50000 geological map and the aerial panchromatic coverage acquired in 2002 at the 1:20000 scale by the Direction Régionale des Eaux et Forêts (DREF) of Marrakech. As soil protection was not directly visible on remotely sensed documents, it was estimated using recorded field measurements based on landscape stratification, intersecting the geological map with the land use types interpreted from the aerial photographs. Soil surface characteristics were observed on these landscape units along transects (one observation every $20 \mathrm{~cm}$ along $20 \mathrm{~m}$ lines). The main variables observed were the stone, vegetation and bare soil coverage, allowing computation of the fraction of soil protected by stones or vegetation.

\subsubsection{Erosion class parameterization}

The combination of the three STREAM parameters produced erosion classes for which we had to assign infiltration rate and sediment concentration values. For the classes corresponding to the locations of measurements sites, observed infiltration rates and sediment concentration were taken into account for the model parameterization (Cheggour, 2008a), whereas for the other classes we had to extrapolate or interpolate the values based on our expert knowledge of the area.

Riverbeds play an important role regarding sediment transportation to the outlet, demonstrating specific hydrological and erosive characteristics. To account for these processes, the drainage network was extracted from the DEM, and it was considered to be infiltrating but not eroding for two reasons. The first one is that the scaling of plot measurements to the watershed level and their comparison with outlet measurements showed that the annual sediment delivery ratio (SDR) was close to one (Cheggour 2008a). The second reason is that visual observations of the riverbeds showed that they were mainly stony with no evidence of significant bank erosion or deposition areas over the long term. Some temporary deposits were locally visible in flat areas of the riverbeds, but they were likely to be removed during subsequent flood events and would not accumulate over the long term. 


\subsubsection{Rainfall spatialization}

As the duration and maximum intensity of events were only available for the two automatic rain gauges, these values were extrapolated to the neighboring manual gauges based on an analysis of the automatic gauges' data. The duration of the events was found to be significantly proportional to depth $\left(0.21 \mathrm{~h} \mathrm{~mm}^{-1}, \mathrm{R}^{2}=0.85\right.$, p-value $\left.<10^{-3}\right)$, and the maximum intensity in five minutes was weakly but significantly linked to depth (slope $0.42 \mathrm{~mm} \mathrm{~mm}^{-1}$, $R^{2}=0.25$, $p$-value $<10^{-3}$ ). The spatialization of the rainfall characteristics was performed using Thiessen polygons to produce homogeneous areas. We assumed that this method was appropriate considering the uncertainties associated with the data. Finally, assuming that neither snow precipitation nor the subsequent snowmelt produced significant erosion, snowfall areas were removed for each event, based on temperatures recorded by an automatic station and a gradient linked to elevation that was distributed over ten classes.

\subsection{Building scenarios of climate and land use changes}

\subsubsection{Climate change scenarios}

Daily rainfall data records were available for the period 1989-2008 at the outlet of Tahanaout, which has the advantage of being close to areas that produce the more erosion. This time series (RHE) allowed the computation of the statistical distribution of rainfall events in 10 depth classes for each month. Changes were estimated based on outputs provided by the global general circulation model ARPEGE Météo France v4. (Deque, 2007) for the 30-year 1960-1990 (re-analysis, REF) and 2070-2100 periods. The A1B emission scenario was used for the latter period, as it was considered the closest to business as usual, with a steady global growth and a balance across energy sources (IPCC, 2013). Only the ARPEGE grid point closest to the Rheraya was considered for the change analysis. The comparison of REF and A1B allowed the computation of changes in the frequencies of each class of rainfall depth for each month. Because of the scale of the ARPEGE data and the high spatial variability of climate due to relief, even the closest point is by no means representative of Rheraya rainfall. Thus, changes computed from this grid point datum were applied to the actual Rheraya data (RHE) in a downscaling procedure. Three methods were used to compute the depth frequency changes between the REF and A1B scenarios, based on Ruffault et al. (2014).

\section{Monthly depth anomalies method (ANO)}

The underlying hypothesis was that the change ratio in the monthly rainfall depths between REF and A1B could be applied to the actual individual RHE event depths. To achieve this, event depths were summed for each month and the change ratio in the monthly depth between REF and A1B was computed. This monthly change ratio was applied to the depths of the actual events of REF, producing a new series of depths, RHEcc, with the same number of events. The comparison of RHE and RHEcc provided change coefficients for each combination of month and depth class.

\section{Event frequency method (FREQ)}

For each month, the frequency distribution of rainfall depths was calculated for REF and A1B. The anomaly in the frequency distribution between the two scenarios was then applied to the actual rainfall events. This straightforward application of the frequency anomaly implies that if the range of the events' rainfall depths in REF was different from the range in RHE, then changes in annual depth could be far from the ARPEGE changes. This problem may 
occur because the chosen ARPEGE grid cell encompasses a wide variety of environments, including both plains and mountains.

\section{Normalized event frequency method (FREQnorm)}

Finally, we relied on the Quantile Mapping Method (Boe et al., 2007) for analyzing the Mediterranean climate (Ruffault et al., 2014). This method reduced the problems found in the FREQ method by modifying the bounds of the depth classes in REF and A1B so that the transformed REF distribution matched the distribution in RHE, even though the class definitions were no longer the same. Then, the change ratios in the frequency of the new REF and A1B distributions were applied to RHE to produce RHEcc. The underlying hypothesis was that even if the distributions were not the same, the change pattern of sorted events remained the same.

Because the meteorological model does not provide information about the intensity, we assumed that it remains the same for a given depth. Thus, changes were only considered for the distribution of rainfall events, not for their internal structure. It was therefore not necessary to run STREAM for new events, as the simulation work consisted of combining the existing events with weighting factors related to the frequency changes of their month and depth class.

\subsubsection{Land use change scenarios}

The scenarios were driven by the following factors: (1) the pressure conditioning the rangelands' degradation status (RG); (2) the area of dry cultivation (DC), with possible extensions mainly on neighboring rangelands, flat lands, and calcareous substratum; and (3) the area of the badlands $(\mathrm{BL})$, either benefiting from conservation practices or, conversely, extending on neighboring areas of clay loam substratum. These physical factors are conditioned by complex socio-economical processes and may not change independently, but we decided to consider the following arbitrary six potential scenarios:

- Degradation $\mathrm{DC}^{*} 2$ : Dry cultivation development with a doubling of their areas.

- Degradation of RL: Grazing development: Degradation of all rangeland areas due to overgrazing or climate change.

- Degradation of $\mathrm{RL}, \mathrm{DC} \mathrm{C}^{*} 2, \mathrm{BL}^{*} 2$ : Overall increase of pressure: Degradation of rangelands, doubling of dry cultivation areas and doubling of badlands areas.

- Degradation of $R L+B L^{*} 4$ : Strong increased pressure on natural areas: Degradation of rangelands and badlands area extending four times.

- Protection of RL: Improvement of rangelands by grazing control rules.

- Protection of $\mathrm{RL}$ and $\mathrm{BL}$ : Improvement of rangelands and conservation practices applied on all badlands.

\section{Results and discussion}

\subsection{Field measurements and STREAM parameterization}

A land use map was issued by photo interpretation of aerial photographs, and it showed the following classes: bare rocks, rangeland, natural forest, forest plantation, dry cultivation, 
irrigated crops and rivers. The soil type was derived from the combination of both the geological map and the land use, including the following seven classes: bare rocks, magmatic rocks, downslope colluviums (on magmatic substratum), clay material, clay loam material, basalt and rivers (Fig. 3). Soil conservation practices included forest plantations settled on embankments on the slopes and irrigated crops in the valleys. The resulting map was binary, showing either the presence or absence of conservation practices (Fig. 3). Finally, to characterize the soil protection, landscape units were obtained from a combination of the geology and land use. The soil surface characteristics were observed through 69 transects on these major units, and three soil protection classes were identified: bare soil, less than $70 \%$ soil coverage and more than $70 \%$ soil coverage (Fig. 3). The bare soil class mainly included badlands and dry cultivation areas. The combination of the seven soil classes, the two soil conservation classes and the three soil protection classes produced 42 classes for which we had to assign infiltration rate and sediment concentration values. 

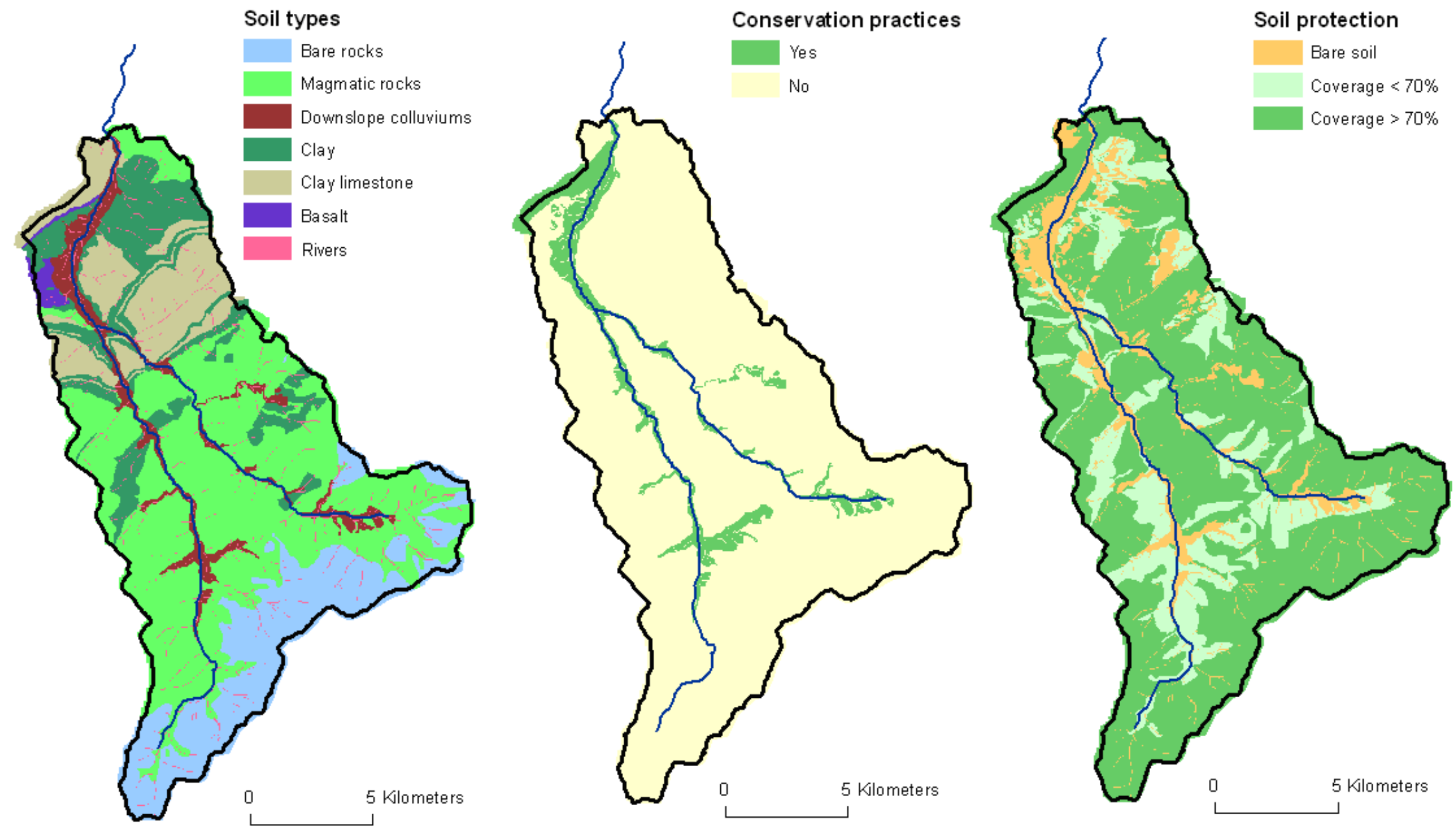

Fig. 3. Maps of the three input parameters in STREAM used to determine infiltration rate and sediment concentration classes (soil type, conservation practices, soil protection). 
Detailed results of the runoff and sediment yield measurements were described by Cheggour et al. (2008a, 2008b). An average annual rainfall depth of $367 \mathrm{~mm}$ was recorded during the four years of the experiment. For the two automatic gauges, the average rainfall depth of the events was $11 \mathrm{~mm}$, with an absolute maximum of $131 \mathrm{~mm}$. The average maximum rainfall intensity in five minutes was $11 \mathrm{~mm} \mathrm{~h}^{-1}$, with an absolute maximum of $118 \mathrm{~mm} \mathrm{~h}^{-1}$. Very little runoff and sediment yield were observed on most of the plots-between 0.015 and $2.5 \mathrm{tha}^{-1}$ $\mathrm{y}^{-1}$ (Cheggour, 2008a). Conversely, runoff and sediment yield were very high on the clay loam areas of badlands (approximately $400 \mathrm{t} \mathrm{ha}^{-1} \mathrm{y}^{-1}$ ). The STREAM parameters defining infiltration rate and sediment concentration were determined using both erosion plots and infiltration test data, as detailed in tables 1 and 2.

Table 1. Left table: Infiltration classes related to the three driving parameters. (p) indicates the combinations for which plot data were available. Right table: Infiltration rate value associated with each class.

\begin{tabular}{|c|c|c|c|c|}
\hline \multirow[b]{2}{*}{ Geology } & \multirow[b]{2}{*}{$\begin{array}{c}\text { Soil } \\
\text { conservation }\end{array}$} & \multicolumn{3}{|c|}{ Soil Protection } \\
\hline & & Bare soil & $\begin{array}{c}\text { Coverage } \\
<70 \%\end{array}$ & $\begin{array}{c}\text { Coverage } \\
>70 \%\end{array}$ \\
\hline \multirow{2}{*}{ Bare rocks } & Yes & 0 & 0 & 0 \\
\hline & No & 0 & 0 & 0 \\
\hline \multirow{2}{*}{ Magmatic } & Yes & 5 & 5 & 5 \\
\hline & No & 4 & $5(p)$ & 5 \\
\hline \multirow{2}{*}{$\begin{array}{l}\text { Downslope } \\
\text { colluviums }\end{array}$} & Yes & 5 & 5 & 5 \\
\hline & No & 4 & $5(p)$ & $5(p)$ \\
\hline \multirow{2}{*}{ Clay } & Yes & 3 & 3 & $4(p)$ \\
\hline & No & $O(p)$ & 1 & 1 \\
\hline \multirow{2}{*}{ Clay limestone } & Yes & 4 & 4 & 4 \\
\hline & No & 1 & $2(p)$ & 3 \\
\hline \multirow{2}{*}{ Basalt } & Yes & 4 & 4 & 4 \\
\hline & No & 3 & 3 & 4 \\
\hline \multirow{2}{*}{ Rivers } & Yes & 4 & 4 & 4 \\
\hline & No & 4 & 4 & 4 \\
\hline
\end{tabular}

\begin{tabular}{|cc|}
\hline $\begin{array}{c}\text { Infiltration } \\
\text { class }\end{array}$ & $\begin{array}{c}\text { Infiltration } \\
\text { value } \\
\left(\mathrm{mm} \mathrm{h}^{-1}\right)\end{array}$ \\
0 & 3.15 \\
1 & 4.5 \\
2 & 5 \\
3 & 5.5 \\
4 & 6 \\
5 & 12 \\
\hline
\end{tabular}


Table 2. Left table: Erosion classes related to the three driving parameters, including the combinations for which plot data $(p)$ or infiltrability tests (it) were available. Right table: Sediment concentration associated with each class.

\begin{tabular}{|c|c|c|c|c|}
\cline { 3 - 5 } \multicolumn{2}{c|}{} & \multicolumn{3}{c|}{ Soil Protection } \\
\hline \multirow{2}{*}{ Geology } & $\begin{array}{c}\text { Soil } \\
\text { conservation }\end{array}$ & Bare soil & $\begin{array}{c}\text { Coverage } \\
<70 \%\end{array}$ & $\begin{array}{c}\text { Coverage } \\
>70 \%\end{array}$ \\
\hline \multirow{2}{*}{ Bare rocks } & Yes & 0 & 0 & 0 \\
\cline { 2 - 5 } & No & 0 & 0 & 0 \\
\hline \multirow{2}{*}{ Magmatic } & Yes & 2 & 1 & 1 \\
\cline { 2 - 5 } colluviums & No & 2 & $\mathbf{2}$ (p, it) & 1 \\
\cline { 2 - 5 } & Yes & 1 & 1 & 1 \\
\hline \multirow{2}{*}{ Clay } & No & 2 & $\mathbf{2}$ (p, it) & $\mathbf{1}$ (p, it) \\
\cline { 2 - 5 } & Yes & 2 & 1 & $\mathbf{1}$ (p, it) \\
\hline \multirow{2}{*}{ Clay limestone } & No & $\mathbf{5}$ (p, it) & 4 & 3 \\
\cline { 2 - 5 } & Yes & 2 & 2 & 1 \\
\hline \multirow{2}{*}{ Basalt } & No & 4 & $\mathbf{3}$ (p, it) & $\mathbf{1}$ (it) \\
\cline { 2 - 5 } & Yes & 3 & 2 & 2 \\
\hline \multirow{2}{*}{ Rivers } & No & $\mathbf{4}$ (it) & $\mathbf{4}$ (it) & 3 \\
\cline { 2 - 5 } & Yes & 0 & 0 & 0 \\
\hline
\end{tabular}

\begin{tabular}{cc|}
$\begin{array}{c}\text { Turbidity } \\
\text { class }\end{array}$ & $\begin{array}{c}\text { Turdibity } \\
\text { value } \\
\left(\mathrm{g} \mathrm{l}^{-1}\right)\end{array}$ \\
0 & 0 \\
1 & 2.7 \\
2 & 4.5 \\
3 & 7 \\
4 & 20 \\
5 & 425 \\
\hline
\end{tabular}

At the watershed scale, the observed annual runoff depth ranged from 77 to $138 \mathrm{~mm}$ and the annual sediment yield ranged from 2.1 to $5.9 \mathrm{t} \mathrm{ha}^{-1} \mathrm{y}^{-1}$, with an average of $4.1 \mathrm{t} \mathrm{ha}^{-1} \mathrm{y}^{-1}$ over the four years of measurement (table 3). An analysis of the daily runoff and sediment yield at the outlet performed by Cheggour (2008a) underlined the irregularity of the erosive process. Most of the sediment discharge occurred during floods, and during the 2004/2005 year a single flood event was responsible for more than half of the annual sediment yield.

Table 3. Annual runoff and sediment yield of the Rheraya watershed at the Tahanaout outlet.

\begin{tabular}{|c|c|c|c|c|c|}
\hline Hydrologic Year & $\begin{array}{c}\text { Annual Rainfall } \\
(\mathrm{mm})\end{array}$ & $\begin{array}{c}\text { Annual Runoff } \\
(\mathrm{mm})\end{array}$ & $\begin{array}{c}\text { Annual Runoff } \\
\left(10^{6} \mathrm{~m}^{3}\right)\end{array}$ & $\begin{array}{c}\text { Annual sediment } \\
\text { Yield }(\mathrm{t})\end{array}$ & $\begin{array}{c}\text { Specific annual } \\
\text { sediment Yield } \\
(\mathrm{t} \mathrm{ha})^{-1}\end{array}$ \\
\hline $2004 / 2005$ & 282 & 77 & 17.5 & 48634 & 2.14 \\
\hline $2005 / 2006$ & 453 & 102 & 23.2 & 136009 & 5.86 \\
\hline $2006 / 2007$ & 394 & 138 & 31.5 & 105177 & 4.61 \\
\hline $2007 / 2008$ & 338 & 121 & 27.5 & 82981 & 3.64 \\
\hline Average & 367 & 109 & 24.9 & 93200 & 4.1 \\
\hline
\end{tabular}




\subsection{STREAM validation}

\subsubsection{Analysis at the event scale}

During the four years of the study, 61 rainfall events produced either simulated or observed runoff at the outlet and were considered for the analysis. The results of STREAM simulations for these events were compared to measurements at the watershed's outlet (Fig. 4). Although the sets of points representing the observed and simulated values of runoff and sediment yield have their centroids close to the 1:1 line, some individual events are clearly not modeled correctly, as they differ by about an order of magnitude. However, this classic result is observed for most of existing models (Jetten et al., 1999). These authors noted, "at a catchment scale, the predicted spatial runoff pattern is as important as a correct prediction of the net output". The use of the STREAM model with explicit spatial calibration based on field measurements follows this direction.

Some relatively small observed floods, mostly below $10^{5} \mathrm{~m}^{3}$, produced no runoff with the model and are located on the X-axis of figure 4. This result may be explained by the slow processes of subsurface runoff and exfiltration, which were not accounted for in STREAM although they may occur in semi-arid areas (Canton et al., 2011). Some important floods, which are visible as points far below the 1:1 line, were also underestimated by the model. They match with events with large rainfall depths and long duration, and thus of low intensity (one event in the year 2005/2006 and one in the year 2007/2008). Such events produced very important subsurface flow, which was not simulated.

Conversely, according to the model, four events produced relatively small floods (below $10^{5} \mathrm{~m}^{3}$ ) that were not observed. They are located on the Y-axis: one in 2005/2006 and three in $2007 / 2008$. Additionally, the model largely overestimated the volumes for some bigger floods as shown by points located far above the $1: 1$ line. Three events of this type are visible in 2004/2005 and another in 2006/2007. Rainfall data showed that these events might be due to an overestimation of the rainfall intensity during the spatialization processes. Indeed, when a strong event-typically a local storm, which is frequent-was recorded at the automatic rain gauge, its intensity was propagated to all neighboring rain gauges, resulting in a strong overestimation of the rain intensity. Conversely, when a strong stormy event was missed because it was not located on a recording gauge, which should also be frequent, the discrepancy between model and measurement was lower because the impact was local.

These events with either no observed or no simulated runoff reveal the limitations of the modeling, although they have a little weight on the annual erosion budget $(2.5 \%$ of sediment yield). 

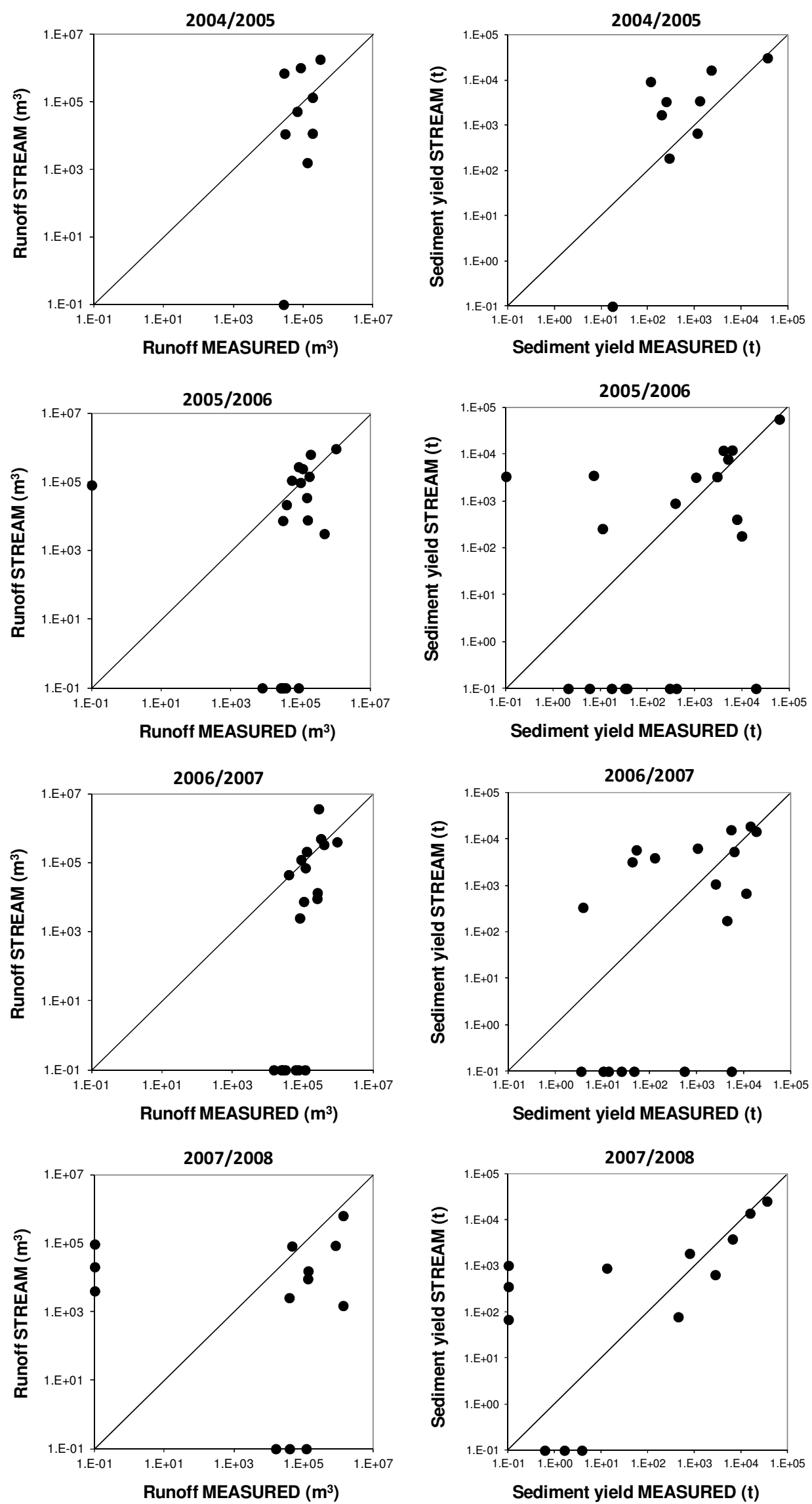

Fig. 4. Comparison of runoff depth and sediment yield at the Rheraya outlet for the four years (01/09/2004-31/08/2008). Axes are in logarithmic scales. 
The comparison between the observed and simulated sediment yield at the outlet showed large under- or overestimates as for the runoff. A closer look at the rainfall spatial distribution (not presented here) revealed that points with an overestimated sediment yield were linked with rainfall events falling on the very erodible soils (red clay loam badlands), whereas points with an underestimated sediment yield were linked with rain falling mainly on less erodible soils (magmatic rocks) south of the basin. The explanation of this trend could be related to an incomplete STREAM representation of sediment deposition and uptake processes during successive events in the riverbed. On the one hand, STREAM underestimated the sediment deposition for events with high rainfall on badlands. On the other hand, it underestimated the uptake of these deposited sediments for events with high rainfall on magmatic rocks upstream. In fact, the hypothesis of a sediment load buffered by sediment deposition and uptake processes during successive events is confirmed by the strong relationship between the peak flow rate and sediment concentration observed at the outlet $\left(R^{2}=0.8\right)$ independent of the location of the rainfall (Fig. 5).

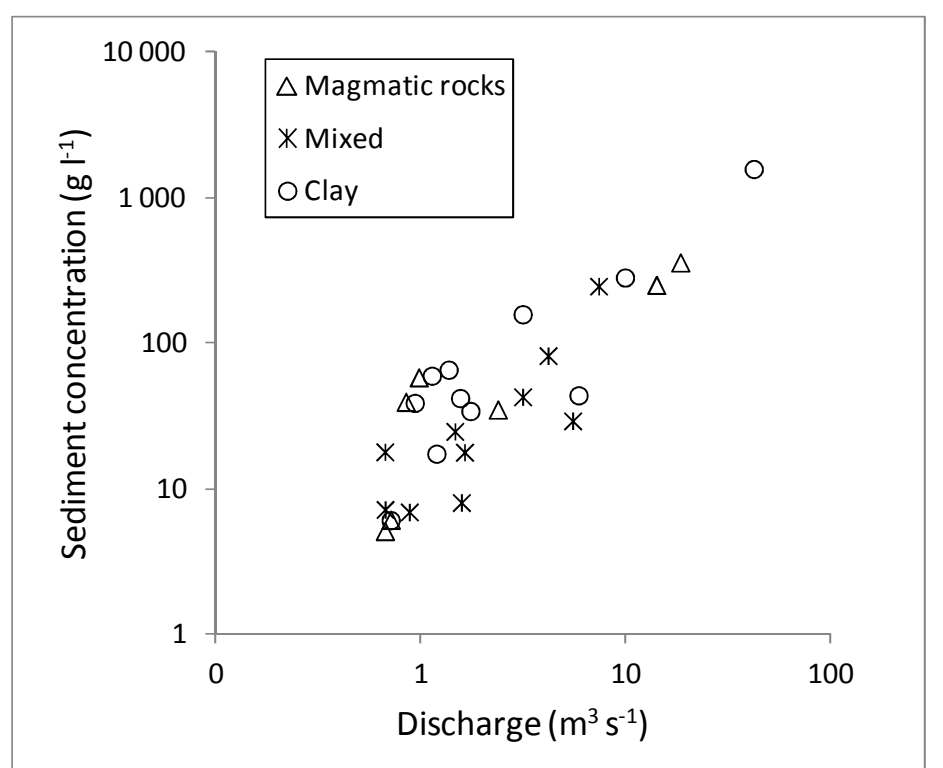

Fig. 5. Relation between peak discharge and sediment concentration at the outlet of the Rheraya watershed. Different symbols correspond to the main rainfall location within the watershed. (from Cheggour et al., 2008a).

\subsubsection{Analysis at the annual scale}

Regarding runoff, the coefficient of determination between the observed and modeled values computed from the 61 events was low, although significant $\left(R^{2}=0.12\right.$, $p$-value $\left.=3 \times 10^{-3}\right)$, showing that simulation was not reliable at event scale. When aggregated into hydrological years, the order of magnitude of the simulated annual runoff was correct but the agreement between the simulated and observed runoff values was not very good except for the year $2005 / 2006$. The annual budget was influenced by large errors related to a small number of events, due either to rainfall spatialization or to the lack of subsurface process modeling. However, at this annual scale, the mean of simulated runoffs was not statistically different 
from the observed values, as shown by the p probabilities in table 4, indicating that there is no significant bias in the model. Moreover, the mean observed and simulated runoff values over the four years of the study were relatively close. Regarding the sediment yields, the relation between the simulated and observed values computed from the 61 events was much better than for runoff $\left(R^{2}=0.79, p\right.$-value $\left.<10^{-4}\right)$. There was also a good overall agreement between the observed and simulated annual values for sediment yield (Table 4). A larger discrepancy was observed for the year 2004/2005, which was previously explained by the three rainfall events that were strongly overestimated for this year.

Table 4. Annual runoff volume and sediment yield observed and simulated by STREAM. $p$ is the probability that the simulated and observed values belong to the same population. All values are above 0.01 , which means that they are significant at the $1 \%$ level.

\begin{tabular}{|c|c|c|c|c|c|}
\hline & & \multicolumn{2}{|c|}{ Runoff } & \multirow[b]{2}{*}{$\begin{array}{l}\text { Sediment yield } \\
\qquad\left(10^{3} \mathrm{t}\right)\end{array}$} & \multirow[b]{2}{*}{$\begin{array}{c}\mathrm{p} \\
\text { (comparison } \\
\text { of averages) }\end{array}$} \\
\hline & & Runoff $\left(10^{6} \mathrm{~m}^{3}\right)$ & $\begin{array}{c}\mathrm{p} \\
\text { (comparison } \\
\text { of averages) }\end{array}$ & & \\
\hline \multirow{2}{*}{$2004 / 2005$} & Measured & 1.02 & \multirow{2}{*}{0.17} & 42.1 & \multirow{2}{*}{0.20} \\
\hline & STREAM & 3.91 & & 75.3 & \\
\hline \multirow{2}{*}{$2005 / 2006$} & Measured & 2.88 & \multirow{2}{*}{0.69} & 119 & \multirow{2}{*}{0.55} \\
\hline & STREAM & 3.07 & & 113 & \\
\hline \multirow{2}{*}{$2006 / 2007$} & Measured & 3.4 & \multirow{2}{*}{0.58} & 69 & \multirow{2}{*}{0.77} \\
\hline & STREAM & 5.7 & & 87 & \\
\hline \multirow{2}{*}{$2007 / 2008$} & Measured & 3.9 & \multirow{2}{*}{0.07} & 63 & \multirow{2}{*}{0.22} \\
\hline & STREAM & 1.2 & & 57 & \\
\hline \multirow{2}{*}{ Average } & Measured & 2.8 & \multirow{2}{*}{0.75} & 73.3 & \multirow{2}{*}{0.98} \\
\hline & STREAM & 3.48 & & 83.3 & \\
\hline
\end{tabular}

The relatively good sediment yield estimates, which occurred despite a less accurate assessment of the runoff, could be explained by the fact that most of the sediments came from the badlands, which were the most sufficiently characterized location. The badlands were well delineated on aerial photographs, heavily documented regarding runoff and erosion during the four years of observation, and located very close to one of the two automatic rain gauges, which gave representative estimates of the rainfall intensity. Therefore, the major rainfall events located on these badlands were the main contributors to the total sediment yield and were accurately simulated. Conversely, the runoff volume at the outlet was more sensitive to the combination of rainfall depth and infiltration rates on the remaining areas (i.e., the majority of the watershed). As stated, the spatialization of the rainfall might have suffered from uncertainties because of the strong relief, despite the 11 rain gauges used. Additionally, infiltration rates were more accurately estimated in badlands than in other areas, which was due to the reduced number of runoff events observed in the latter during the four years of monitoring erosion plots. However, it seems that the recorded infiltration values were overall correct and did not introduce bias despite discrepancies at the event scale, which was partly due to the aforementioned lack of modeled subsurface flow processes. Indeed, the mean of simulated annual runoffs volumes over the four years was comparable to the observed values (respectively 2.8 and $3.48 \times 10^{6} \mathrm{~m}^{3}$ ). Sediment yield was 
not hampered much by runoff problems because of the relative spatial separation of erosion (mainly badlands) and runoff generation (all soils) in this type of landscape.

\subsubsection{Discussion}

The comparison between the event and annual time scales leads us to identify a disjunction in time between the local production of sediments and their exportation at the outlet of the watershed. Gallart et al. (2005) observed the same phenomenon on a similar Mediterranean landscape that included badlands. In both cases, the fact that the sediment source was local (i.e., badlands) and accurately assessed helped to identify the delayed routing processes. This delay in sediment transfer linked to deposition and subsequent uptake is not represented in STREAM, a design choice that is lacking in many models and would deserve conceptual improvements in route modeling (Parsons et al., 2006, Kirkby, 2010). The connectivity concept, which includes a conceptual quantification of this parameter based on the combination of topography and land cover properties (Borselli et al., 2008), was introduced to tackle this problem (Cammeraat, 2004, De Vente et al., 2006). Although sediment routing in STREAM is modeled between neighboring cells, connectivity per se is not explicitly taken into account. This may explain the problems encountered at the event scale. Fryirs (2012) also proposed a formalism to account for sediment trapping and deposition in the natural landscape, though this formalism relies on an intensive characterization of the landscape that has problems in the quantification and spatialization of these parameters.

Aside from routing problems, another important limitation for event scale modeling is the spatial heterogeneity of rainfall, which is potentially very uneven and difficult to assess due to the limited density of the gauge network, especially in mountainous environments. These problems were also analyzed by Lopes (1996), who noted no simple solution for storm events.

At the annual scale, the discrepancies between the observed and modeled sediment yield at the event scale tend to balance out and give satisfactory annual sediment yields. Referring to the SDR concept, our implementation managed to reproduce an SDR close to one, which signifies no significant deposition areas. Referring to the alternate transport-distance approach proposed by Parsons et al. (2006) and Wainwright et al. (2008), this observation means that materials that eroded at the plot scale quickly reached a dense drainage network, where they are then driven to the outlet. In addition, this fact can be interpreted as good connectivity regarding the sediment routing, which is a common feature in natural landscapes (Lesschen et al., 2009). A study of sediment routing in Slovenia (Keesstra et al., 2009) also notes the temporary storage of sediments in rivers beds, although in this case a slight accumulation was observed $(\mathrm{SDR}=0.73)$ which was supposed to be washed up during extreme events.

Despite the noted conceptual limitations regarding process modeling, which prevented obtaining good results at the event scale, the adequate results at the annual scale can be related to the robustness of the parameterization based on a set of representative field measurements. In contrast to complex physical modeling approaches that require many parameters (Wainwright et al., 2008, Smith et al., 2010), STREAM uses direct input of infiltration and sediment concentration values issued from plot measurements, thus avoiding calibration. Indeed, robustness is required for models to be used for decision making in the real world, where specific complex parameterization is not feasible (Renschler and Harbor, 
2005). Considering the satisfactory results obtained at annual scale, the model was used in the subsequent step to simulate the effect of changes in land use and climate over the next century.

\subsection{Modeling future erosion with STREAM}

\subsubsection{Changes in precipitations}

The downscaling of the A1B scenario to the scale of the Rheraya simulated a rainfall decrease by 10 to $14 \%$ compared to the $1960-1990$ period (Table 5) and a change in the distribution of events with more rain in the summer and fall (Fig. 6). The main features of these changes were almost the same for the three downscaling methods; ANO showed the largest difference with more contrasted changes in the distribution. Due to the lack of related information, rainfall intensities were not modified; only the distribution and number of events changed. Conversely, Nunes et al. (2011) chose not to change the number of events but to scale the depth and the intensities of events with the same change factor. Mullan et al. (2011), considering that no prediction of intensity was reliable, achieved a sensitivity analysis on this parameter. Whichever disaggregation method was used, it was clear major uncertainties remained, which were directly linked to the outputs of the climate models.

Table 5. Actual annual rainfall $(\mathrm{mm})$ in the Rheraya watershed compared with the three downscaling methods.

\begin{tabular}{|cccc|}
\hline Rheraya actual & ANO & FREQ & FREQ-NORM \\
357 & 306 & 320 & 313 \\
difference $\%$ & -14 & -10 & -12 \\
\hline
\end{tabular}

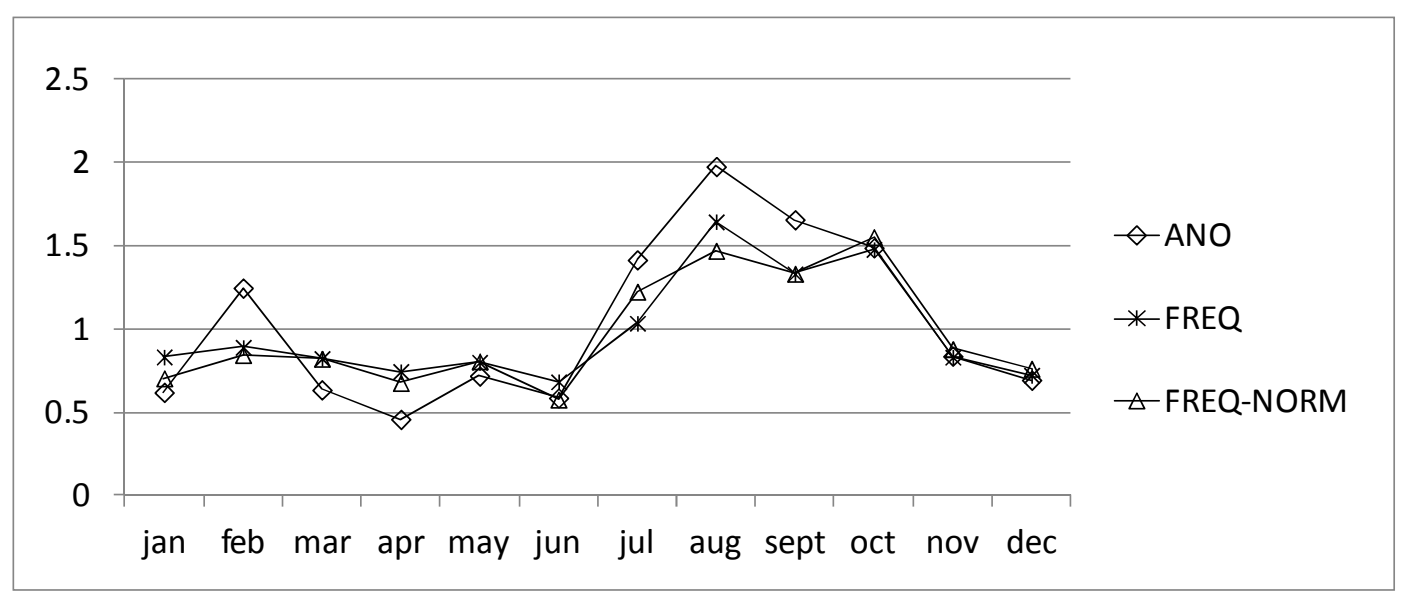

Fig. 6. Ratio of future (A1B) to current (REF) monthly rainfalls for the three precipitation downscaling methods. 


\subsubsection{Changes in erosion}

The results in table 6 show that the climate change alone induced a small increase in the sediment yield, which was estimated between 4.7 and $10.1 \%$ depending on the downscaling method used. The range of these changes is higher than the one obtained for rainfall depth using the same climate disaggregation methods, illustrating the sensitivity of the erosion processes as outlined by previous studies (Parish and Funnell, 1999; Mullan et al., 2011). The erosion increase occurred despite a decrease in the annual precipitation, as it was overcompensated by a distribution change that involved more erosive rainfall events between July and October. Other authors also found that the seasonal distribution and intensity of the events were more important that an overall change in precipitation, which could induce ambivalent effects linked to the interactions of plant biomass, runoff and erosion (Nearing et al. ,2005; Turnbull et al., 2013).

A problem might arise with the prediction of extreme precipitation events that did not occur during the four years of observation. A slight change in the characteristics of such events may have considerable impact on annual budgets (Boardman, 2006). However, we had no mean to make predictions "out of the box"; instead, we just modified the frequencies of events that were already observed. Even if such extreme events were hypothesized, we are not sure that the model would respond correctly. New erosion processes could appear that are not taken into account in our configuration (e.g., linear erosion), which would increase the order of magnitude of soil loss. This concern exacerbates the general scaling problem that is encountered when comparing treatments with different events or extrapolating measurements recorded over a limited time (Kirkby, 2010).

Table 6. Relative changes in sediment yield of the Rheraya watershed for various rainfall and land use change scenarios, for the three downscaling methods. The values are in percentage compared to the actual situation. $\mathrm{RL}$ : rangelands,

BL: badlands, DC: dry cultivation.

\begin{tabular}{|c|c|c|c|c|c|}
\hline & \multicolumn{4}{|c|}{ Climate change downscaling method } & $\begin{array}{c}\text { Land use } \\
\text { change only }\end{array}$ \\
\hline Land use change scenario & ANO & FREQ & FREQ NORM & Average & \\
\hline Degradation $\mathrm{DC} * 2$ & 12.8 & 18.6 & 17.8 & $\mathbf{1 6 . 4}$ & $\mathbf{7 . 4}$ \\
\hline Degradation of $\mathrm{RL}$ & 17.8 & 24.5 & 24.1 & $\mathbf{2 2 . 1}$ & $\mathbf{1 2 . 0}$ \\
\hline Degradation of $\mathrm{RL}, \mathrm{DC}{ }^{*} 2, \mathrm{BL}{ }^{*} 2$ & 119.2 & 129.7 & 125.2 & $\mathbf{1 2 4 . 7}$ & $\mathbf{1 1 2 . 0}$ \\
\hline Degradation of $\mathrm{RL}+\mathrm{BL} 4$ & 257.6 & 282.7 & 271.1 & $\mathbf{2 7 0 . 5}$ & $\mathbf{2 4 9 . 4}$ \\
\hline Protection of $\mathrm{RL}$ & -4.0 & -0.1 & -1.3 & $\mathbf{- 1 . 8}$ & $\mathbf{- 8 . 2}$ \\
\hline Protection of $\mathrm{RL}$ and $\mathrm{BL}$ & -85.3 & -82.4 & -81.3 & $\mathbf{- 8 3 . 0}$ & $\mathbf{- 8 6 . 3}$ \\
\hline Climate change only & 4.7 & 10.1 & 8.9 & $\mathbf{7 . 9}$ & \\
\hline
\end{tabular}


The variation within the land use changes was approximately $10 \%$ for changes related only to dry cultivation or rangeland classes. The badlands class had a much larger impact on sediment yield, as it induced changes that were roughly correlated to the variation of their area. Despite the larger uncertainty associated with erosion rates on other land use classes, the magnitude of this difference indicates the major importance of badlands on the watershed budget. The direct extrapolation of erosion plot measurements to the whole watershed, which was based on vegetation cover and lithology, showed that the badlands were producing $95 \%$ of the soil erosion, although they covered only $1.2 \%$ of the total area (Cheggour, 2008a). Conservation practices were applied on these areas in the 1960s, but a lack of maintenance has considerably reduced their efficiency (Cheggour, 2008a).

The simulation of land use changes consisted of modifying the classes of some land use patches to comply with the scenarios. The underlying hypothesis was that temporal changes were already included in the present spatial variability of the landscape in a manner similar to Imeson and Lavee (1998), who studied topographic transects representing various stages of degradation in order to quantify potential future changes. This was possible here thanks to the plot data used for parameterization, which encompassed the major levels of degradation.

The effects of climate and land use change scenarios were combined without mechanistically considering the possible synergies between parameters - i.e., the indirect effects mentioned in the introduction. These complex interactions between climate, soil and vegetation were heavily studied (e.g., Imeson and Lavee, 1998, Garcia-Fayos and Bochet, 2009) and may be used to build relevant models of erosion that account for climate changes. In line with this approach, Nunes et al. (2011) used the SWAT model to simulate climate-induced changes in natural vegetation and soil, which were then integrated into an erosion model. Although such interactions were not considered here, the various land use scenarios tested were contrasted enough and thus may have already included the possible magnitude of indirect climatic effects. In this regard, it appears that on top of the effects of rainfall, the variation of the badlands area overwhelms the potential magnitude of changes regarding the other land uses. Thus, although the effects of climate on vegetation may indirectly contribute to changes in the extent of the badlands, the anthropogenic factor is of foremost influence in mitigating or, conversely, extending their area through overgrazing.

Sediment yield is a direct threat, especially for dams in Morocco due to siltation. In addition, the ecological functions of soils, e.g., the forage production of rangelands, may also be affected by erosion (Yisehak et al., 2013) and must be related to the soil depth and its generation rate though pedogenesis (Renschler and Harbor, 2005). This aspect was not quantified in the study area, but visual observations clearly showed very shallow soils, although their depth was quite heterogeneous. Moreover, the number of visible signs of erosion, such as exposed tree roots and recent bare parent rocks, indicated that erosion was faster than renewal.

\section{Conclusion}

Although STREAM was designed for temperate agricultural areas, we managed to implement the model in the context of semi-arid mountains that were mainly occupied by rangelands. Three major parameters driving runoff rate and sediment concentration, namely soil type, soil protection by vegetation or stones and existence of soil conservation practices, 
were identified and their spatial variability within the monitored watershed was described. A comparison between the observed and simulated results allowed us to identify the potentialities and limitations of the model.

The lack of subsurface flow processes lead to some underestimation in the runoff simulation. Additionally, the riverbed processes, including the deposit and subsequent uptake of sediments, which contributed to the buffering of the sediment charge, were not represented. Our results also evidenced the problems associated with rainfall spatialization and the importance of a dense rain gauge network in assessing this input parameter for mountain erosion modeling.

Nevertheless, STREAM was able to produce correct estimates of sediment yield at the annual scale because significant field measurements were available for parameterization, particularly for badlands, which are the most erodible areas.

The simulation of global change scenarios required downscaling methods. Although the three methods tested here gave similar results, they may have shown biases that remained unknown. This might be a problem as the watershed was located in a very heterogeneous grid cell of the global climatic models, a result of the contrasted topography. The results showed that although precipitation should decrease by $10 \%$ by the end of the 21 st century, the change in the temporal distribution would induce an erosion increase of approximately 5 to $10 \%$, assuming similar rainfall intensities. However, climate changes alone might be of minor importance compared to changes in land use, especially the evolution of badlands, which are closely conditioned by human actions. It is thus very important for watershed managers to apply mitigation strategies directed to land and soil conservation, including their maintenance.

\section{Acknowledgements}

This work was financially supported by the National Research Agency (ANR-VMC 2006) through the research project MESOEROS21. We are also grateful to the "Institut de Recherche pour le Développement" (IRD) for funding the SudMed project, as well as the French "Ministère des Affaires Étrangères" and the Moroccan "Ministère de l'Éducation Nationale, de l'Enseignement supérieur, de la Recherche Scientifique et de la Formation des Cadres" for funding the "Programme d'Action Intégrée Volubilis" "Gestion durable des ressources en eau dans le bassin-versant de Tensift (région de Marrakech) " $n^{\circ} M A / 148 / 06$. We also thank the ABHT (Agence de Bassin Hydraulique du Tensift) for providing us with rainfall and streamflow data and the "Direction Régionale des Eaux et Forêts" for their facilitation in the installation of erosion plots.

\section{References}

Boardman, J., 2006. Soil erosion science: Reflections on the limitations of current approaches. Catena 68, 73-86.

Boe, J., Terray, L., Habets, F., Martin, E., 2007. Statistical and dynamical downscaling of the Seine basin climate for hydro meterological studies. Int. J. climatol. 27, 1643-1655.

Borselli, L., Cassi, P., Torri, D., 2008. Prolegomena to sediment and flow connectivity in the landscape: A GIS and field numerical assessment. Catena 75, 268-277.

Cammeraat, E.L.H., 2004. Scale dependent thresholds in hydrological and erosion response of a semi-arid catchment in southeast Spain. Agr. Ecosyst. Environ. 104, 317-332. 
Cantón, Y., Solé-Benet, A., de Vente, J., Boix-Fayos, C., Calvo-Cases, A., Asensio, C., Puigdefábregas, J., 2011. A review of runoff generation and soil erosion across scales in semiarid south-eastern Spain. J. Arid Environ. 75, 1254-1261.

Casalí, J., Giménez, R., De Santisteban, L., Álvarez-Mozos, J., Mena J., Del Valle de Lersundi J., 2009. Determination of long-term erosion rates in vineyards of Navarre (Spain) using botanical benchmarks. Catena 78, 12-19.

Cerdà, A., 1997. Soil erosion after land abandonment in a semiarid environment of Southeastern Spain. Arid Soil Res. Rehab. 11, 163-176.

Cerdan, O., Souchère, V., Lecomte, V., Couturier, A., Le Bissonnais, Y., 2002. Incorporating soil surface crusting processes in an expert-based runoff model: Sealing and Transfer by Runoff and Erosion related to Agricultural Management. Catena 46, 189-205.

Cerdan, O., Govers, G., Le Bissonnais, Y., Van Oost, K., Poesen, J., Saby, N., Gobin, A., Vacca, A., Quinton, J., Auerswald, K., Klik, A., Kwaad, F.J.P.M., Raclot, D., Ionita, I., Rejman, J., Rousseva, S., Muxart, T., Roxo, M.J., Dostal, T., 2010. The rate and spatial distribution of soil erosion in Europe. Geomorphology 122, 167-177.

Chaponnière, A., Boulet, G., Chehbouni, A., Aresmouk, M., 2008. Understanding hydrological processes with scarce data in a mountain environment. Hydrol. Process. 22, 1908-1921.

Cheggour, A., 2008a. Mesures de l'érosion hydrique à différentes échelles spatiales dans un bassin versant montagneux semi-aride et spatialisation par des techniques S.I.G : Application au bassin versant de la Rhéraya, Haut Atlas, Maroc. Thèse de doctorat, Faculté des Sciences Semlalia, Marrakech, Maroc.

Cheggour, A., Simonneaux, V., Asma, S., Yaro, Y., Sadik, E., Sabir, M., Roose, E., 2008b. Recherche d'indicateurs de ruissellement et des risques d'érosion au moyen de tests d'infiltrométrie dans le bassin versant du Rhéraya (Haut-Atlas occidental, Maroc). Rev. Sci. Eau 21, 311-322.

Deque, M., 2007. Frequency of precipitation and temperature extremes over France in an anthropogenic scenario: model results and statistical corrections according to observed values. Global Planet. Change 57, 16-26.

De Vente, J., Poesen, J., Bazzoffi, P., Rompaey, A.V., Verstraeten, G., 2006. Predicting catchment sediment yield in Mediterranean environments: the importance of sediment sources and connectivity in Italian drainage basins. Earth Surf. Proc. Land. 31, 1017-1034.

Evrard, O., Cerdan, O., Van Wesemael, B., Chauvet, M., Le Bissonnais, Y., Raclot, D., Vandaele, K., Andrieux, P., Bielders, C., 2009. Reliability of an expert-based runoff and erosion model: Application of STREAM to different environments. Catena 78, 129-141.

Fleskens, L., Stroosnijder, L., 2007. Is soil erosion in olive groves as bad as often claimed? Geoderma 141, 260-271.

Frot, E., Van Wesemael, B., 2009. Predicting runoff from semi arid hillslopes as source areas for water harvesting in the Sierra de Gador, southeast Spain. Catena 79, 83-92.

Fryirs, K., 2012. (Dis)connectivity in catchment sediment cascades: A freshlook at the sediment delivery problem. Earth Surf. Proc. Land. 38, 30-46,

Gallart, F., Balasch, J.C., Regues, D., Soler, M., Castelltort, X., 2005. Catchment dynamics in a Mediterranean mountain environment: the Vallcebre research basins (south eastern Pyrenees) II: temporal and spatial dynamics of erosion and stream sediment transport. In Catchment Dynamics and River Processes: Mediterranean and Other Climate Regions. Celso Garcia, Ramon J. Batalla, Editors, Elsevier.

Garcia-Fayos, P., Bochet, E., 2009. Indication of antagonistic interaction between climate change and erosion on plant species richness and soil properties in semiarid Mediterranean ecosystems. Global Change Biol. 15, 306-318 
Ghanam, M., 2003. La désertification au Maroc - Quelle stratégie de lutte? 2nd FIG Regional Conference Marrakech, Morocco, 2-5. http://www.fig.net/pub/morocco/proceedings/TS4/TS4_5_ghanam.pdf.

Giorgi, F., Lionello, P., 2008. Climate change projections for the Mediterranean region. Global Planet. Change 63, 90-104.

Imeson, A.C., Kirkby, M.J., 1996. Scaling up processes and models from the field plot to the watershed and regional areas. J. Soil Water Conserv. 51, 391-396.

Imeson, A.C., Lavee, H., 1998. Soil erosion and climate change: the transect approach and the influence of scale. Geomorphology 23, 219-227.

IPCC 2013, Climate Change 2013, The Physical Science Basis. Working Group I Contribution to the Fifth Assessment Report of the Intergovernmental Panel on Climate Change Climate change and water. Tech. rep., Intergovernmental Panel on Climate Change. http://www.climatechange2013.org/images/report/WG1AR5_SPM_FINAL.pdf

Jetten V., de Roo A., Favis-Mortlock D., 1999. Evaluation of field-scale and catchment-scale soil erosion models. Catena 37, 521-541.

Jetten, V., Favis-Mortlock, D., 2006. Modelling soil erosion in Europe, in: Boardman, J., Poesen, J., (Eds.), Soil Erosion in Europe. John Wiley \& Sons, Chichester, pp. 695-716.

Keesstra, S.D., Bruijnzeel, L.A., Van Huissteden, J., 2009. Meso-scale catchment sediment budgets: combining field surveys and modeling in the Dragonja catchment, southwest Slovenia Meso-scale catchment sediment budgets. Earth Surf. Proc. Land. 34, 1547-1561.

King, C., Lecomte, V., Le Bissonnais, Y., Baghdadi, N., Souchère, V., Cerdan, O., 2005. Use of remote sensing data as alternative inputs in the "STREAM" runoff model. Catena 62, 125-135.

Kirkby, M.J., 2010. Distance, time and scale in soil erosion processes. Earth Surf. Proc. Land. 35, 1621-1623.

Kosmas, C., Danalatos, N., Cammeraat, L., Chabart, M., Diamantopoulos, J., Farand, R., Gutierrez, L., Jacob, A., Marques, H., Martinez-Fernandez, J., Mizara, A., Moustakas, N., Nicolau, J., Oliveros, C., Pinna, G., Puddu, R., Puigdefabregas, J., Roxo, M., Simao, A., Stamou, G., Tomasi, N., Usai, D., Vacca, A., 1997. The effect of land use on runoff and soil erosion rates under Mediterranean conditions. Catena 29, 45-59.

Le Bissonnais, Y., Blavet, D., Noni, G., Laurent, J., Asseline, J., Chenu, C., 2007. Erodibility of mediterranean vineyard soils : relevant aggregate stability methods and significant soil variables. Eur. J. Soil Sci. 58, 188-195.

Lesschen, J.P., Schoorl, J.M., Cammeraat, L.H., 2009. Modelling runoff and erosion for a semi-arid catchment using a multi-scale approach based on hydrological connectivity. Geomorphology 109, 174-183.

Lopes, V.L., 1996. On the effect of uncertainty in spatial distribution of rainfall on catchment modelling. Catena 28, 107-119.

Mullan, D., Favis-Mortlock, D., Fealy, R., 2011. Addressing key limitations associated with modelling soil erosion under the impacts of future climate change. Agric. Forest Meteorol. 156, 18-30.

Nearing, M., Jetten, V., Baffaut, C., Cerdan, O., Couturier, A., Hernandez, M., Le Bissonnais, Y., Nichols, M., Nunes, J., Renschler, C., Souchère, V., Van Oost, K., 2005. Modelling response of soil erosion and runoff to changes in precipitation and cover. Catena 61 , 131-154.

Nunes, J.P., Seixas, J., Keizer, J.J., 2011. Modeling the response of within-storm runoff and erosion dynamics to climate change in two Mediterranean watersheds: A multi-model, multi-scale approach to scenario design and analysis. Catena 102, 27-39.

Olesen, J., Bindi, M., 2002. Consequences of climate change for european agricultural productivity, land use and policy. Eur. J. Agron. 16, 239-262. 
Parish, R., Funnell, D.C., 1999. Climate change in mountain regions: some possible consequences in the Moroccan High Atlas. Glob. Environ. Chang. 9, 45-58.

Parsons, A.J., Brazier, R.E., Wainwright, J., Powell, D.M., 2006. Scale relationships in hillslope runoff and erosion. Earth Surf. Proc. Land. 31, 1384-1393.

Ramos, M.C., Martínez-Casasnovas, J.A., 2009. Impacts of annual precipitation extremes on soil and nutrient losses in vineyards of NE Spain. Hydrol. Process. 23, 224-235.

Renschler, C.S., Harbor, J., 2005. Soil erosion assessment tools from point to regional scales - the role of geomorphologists in land management research and implementation. Geomorphology 47, 189-209.

Ruffault, J., Martin St Paul, N.K., Duffet, C., Goge, F., Mouillot, F., 2014.. Projecting drought in Mediterranean forests: bias correction of climate models matters!. Theor. App. Climatol. 117, 113-122.

Smith, R.E., Quinton, J., Goodrich, D.C., Nearing, M., 2010. Soil-erosion models: where do we really stand? Earth Surf. Proc. Land. 35, 1344-1348.

Takken, I., Beuselinck, L., Nachtergaele, J., Govers, G., Poesen, J., Degraer, G., 1999. Spatial evaluation of a physically-based distributed erosion model : LISEM. Catena 37, 431-447.

Turnbull, L., Parsons, A.J., Wainwright, J. \& Anderson, J.P. (2013). Runoff responses to long-term rainfall variability in a shrub-dominated catchment. J. Arid Environ. 91, 88-94.

Vauchel, P., 2005. Hydraccess v 2.1.4 : Logiciel de gestion et traitement de données hydrométéorologiques. Institut de Recherche pour le Développement (IRD), Paris, France.

Wainwright, J., Parsons, A.J., Müller, E.N., Brazier, R.E., Powell, D.M., Fenti, B., 2008. A Transport Distance Approach to Scaling Erosion Rates: 1. Background and Model Development. Earth Surf. Proc. Land. 33, 816-828.

Yisehak, K., Belaya, D., Tayea,, T., Janssens, Geert P.J., 2013, Impact of soil erosion associated factors on available feed resources for free-ranging cattle at three altitude regions: Measurements and perceptions. J. Arid Environ. 98, 70-78. 